\title{
Nursing workload: influence of indirect care interventions*
}

\author{
Carga de trabalho de enfermagem: influência das intervenções de cuidados indiretos \\ Carga laboral de enfermería: influencia de las intervenciones de cuidados indirectos
}

How to cite this article:

Souza P, Cucolo DF, Perroca MG. Nursing workload: influence of indirect care interventions. Rev Esc Enferm USP. 2019;53:e03440. DOI: http://dx.doi. org/10.1590/S1980-220X2018006503440

\author{
Priscilla de Souza ${ }^{1}$ \\ Danielle Fabiana Cucolo ${ }^{2}$ \\ Marcia Galan Perroca ${ }^{3}$ \\ * Extracted from the dissertation: "Influência \\ das intervenções de cuidados indiretos \\ sobre a carga de trabalho de enfermagem", \\ Programa de Pós-Graduação da Faculdade de \\ Medicina de São José do Rio Preto, 2018. \\ ${ }^{1}$ Hospital de Base, Setor de Qualidade, \\ São José do Rio Preto, SP, Brazil. \\ 2 Universidade Federal de São Carlos, \\ Departamento de Enfermagem, \\ São Carlos, SP, Brazil. \\ 3 Faculdade de Medicina de São José do \\ Rio Preto, Departamento de Enfermagem \\ Especializada, São José do Rio Preto, SP, Brazil.
}

\begin{abstract}
Objective: To evaluate nurses' perception of the degree of interference of indirect care interventions on the team's workload and to verify the association between these interventions and the professional and institutional variables. Method: A research survey through e-mail conducted with clinical nurses, unit managers and service managers from eight Brazilian states. A questionnaire containing 28 indirect care interventions and their definitions proposed by the Nursing Interventions Classification was applied. Results: A total of 151 clinical nurses participated, and a response rate of $14.8 \%$ was obtained. The indirect care interventions reported as those which most increase the workload were: Preceptor: employee $(M=3.2)$, Employee Development $(M=3.1)$, Physician Support $(\mathrm{M}=3.0)$ and Conflict mediation $(\mathrm{M}=3.0)$. Statistically significant associations between the investigated interventions and the institutional variables (legal nature and size) were evidenced. Conclusion: Nurses in different practice scenarios perceive that indirect care interventions influence the workload in a differentiated way, with emphasis on the demands related to the monitoring and qualification of employees.
\end{abstract}

\section{DESCRIPTORS}

Workload; Workflow; Time Management; Nursing Staff, Hospital.
Corresponding author:

Marcia Galan Perroca

Av. Brigadeiro Faria Lima 5416 - Vila São Pedro CEP 15090-000 - São José do Rio Preto, SP, Brazil marcia.perroca@gmail.com
Received: 03/07/2018

Approved: 08/20/2018 


\section{INTRODUCTION}

In order for care management to take place there is an articulation of the dimensions of care and management, being equally important and complementary ${ }^{(1)}$. The care interface includes direct care interventions (patient/family interaction) and indirect care interventions (activities to support direct care interventions at a distance, involving unit management and interdisciplinary collaboration) $)^{(2)}$.

The time spent implementing these interventions determines the team's workload, constituting an ongoing complex and challenging subject ${ }^{(3)}$. One of the criticisms is that the different approach forms do not include the complexity of the activities, the procedures, or the dynamics of nursing work $^{(4)}$. It is also agreed that the concept is multifactorial, and researchers ${ }^{(5-6)}$ argue that the workload is not limited to direct patient care and have performed investigations to identify other factors which may interfere with it.

In an attempt to unify several existing concepts, the proposal for a new construct emerged and was therefore adopted as an object of analysis in this investigation. In it, workload is understood as the amount of physical and/or cognitive time and effort required to perform patients' direct and indirect care, as well as non-patient activities (educational activities, problems with equipment and supplies, waiting time, among others) $)^{(7)}$.

The planning and quantitative-qualitative evaluation of the nursing team integrates important management tools in order to guarantee safe care to the patient/family, requiring adequate methods and instruments for its accomplishment ${ }^{(3,8)}$. A lack of uniformity in concepts interferes with the way the workload is measured and generates discredit on the part of nurses. Many are dissatisfied with the traditionallyused instruments for their inability to capture the complexity of their work and provide quality in the care process ${ }^{(5,9)}$.

The activities/interventions performed by the nursing team and the time required for their performance have become a widely discussed topic due to their impact on the quality of patient care/safety and staff working conditions ${ }^{(10-12)}$. Research on the distribution of work time in different practices and specialization settings shows a higher percentage of time consumed by indirect care interventions by nurses $-35 \%^{(13)}$ to $50 \%{ }^{(14)}$. Even so, such interventions have not been adequately considered in the workload measurement instruments.

This investigation is part of the project entitled "Workload Dimensions: Factors not related to Patient Care Complexity” "As Dimensões da Carga de Trabalho: Fatores não Relacionados à Complexidade Assistencial do Paciente"), linked to the Health Services and Nursing Services (GESTSAÚDE) research group, and was conducted in an attempt to fill gaps which still exist in this area. The study aims to evaluate the nurses' perception on the degree of interference of indirect care interventions in the team's workload and to verify the association between these interventions and professional and institutional variables. The questions to be investigated are: "What are the indirect care interventions that most influence the nursing team's workload? With what intensity? Is there an association between these interventions and the professional and institutional variables?"

\section{METHOD}

\section{STUDY DESIGN}

The e-mail survey method was adopted in this study.

\section{Population}

The convenience sample was composed of $151 \mathrm{clini}^{-}$ cal nurses, constituting managers of hospitalization and service units linked to hospitals of different sizes, legal characteristics and relationship with the health system in eight states of the national territory (Pará, Piauí, Ceará, Minas Gerais, Rio de Janeiro, São Paulo, Paraná and Rio Grande do Sul).

\section{Data collection}

Professional social networks were used to establish contact (such as Linkedin), and the snowball sampling method. Of the 1,020 retained e-mails, 151 returned, thereby obtaining a response rate of $14.8 \%$.

Constructing the instrument for data collection followed three steps:

1. The list of indirect care interventions was based on the Nursing Interventions Classifications (NIC) and on Brazilian(13-17) and international(5-6) surveys on workload measurement.

2. Elaborating the online questionnaire - mapping indirect care interventions made it possible to generate a self-administered online questionnaire in the Google Drive program, containing two parts. The first included the clear and Informed Consent Form (ICF), data on the institution, as well as personal and professional characteristics of the respondents. The next part had a Likert scale of four points $(1-$ does not increase, 2 - slightly increases, 3 - moderately increases and 4 - greatly increases the workload), containing a list of 28 indirect care interventions defined according to the NIC.

3. Validation and application of the questionnaire - the constructed on-line questionnaire was evaluated by three clinical nurses and five doctor nurses in terms of the representativeness and clarity of its content. The agreement obtained varied from $98 \%$ to $100 \%$, thus establishing the instrument's content validity. A Cronbach's alpha of 0.90 was found in the internal consistency calculation, considered to be very good.

A pre-test was carried out before the questionnaire was sent to the respondents by four nurses who professionally practice in different units of large hospitals. At this stage they were asked to respond to the instrument, evaluating their objectivity and clarity. Readjustments were performed on some items in order to allow greater understanding. An invitation with the access link was sent to the participants, establishing 15 days to return the questionnaires. The collection occurred from June to December 2015. 


\section{DATA ANALYSIS AND PROCESSING}

The data were computed by the IBM SPSS Statistics v.22 program (IBM Corporation, Armonk, NY). The variables investigated were: 1 . The 28 indirect care interventions; 2 . Type of hospital: public, private, teaching; 3. Size of the institution: small, medium, large and extra capacity; 4. Position or function exercised by the participant: assistance, supervisor/coordinator, manager or teacher; 5. Action units: Hospitalization Unit (HU); Emergency, Intensive Care Unit (ICU), Diagnostic and Therapeutic Support Services (DTSS), Specialized Units (SPU) and Administrative Services (ADMS).

The open responses were categorized and grouped according to the study proposal. The Likert scale was considered as an ordinal level of measurement, and the median, quartiles $(\mathrm{Q} 1$ and $\mathrm{Q} 3)$ and interquartile range $(\mathrm{QA}=\mathrm{Q} 3-\mathrm{Q} 1)$ were calculated. Percentages, mean, standard deviation and confidence interval (CI) of $95 \%$ were calculated for the descriptive analysis. The significance level was set at $\mathrm{p} \leq 0.05$, and the following tests were conducted: 1 . Chi-square to evaluate the association between the nominal variables and in each of the 28 interventions; 2 . Kruskal-Wallis to compare three or more variables, and also to establish the differences between the subgroups of the workload graduations (1 - does not increase and 2 - increases little versus 3 - increases moderately and 4 - greatly increases) and associate them with professional and institutional variables. Those with a mean value of $\geq 3.0$ (moderately increased or greatly increased workload) were considered as more representative to assess the impact on indirect care interventions on the nursing team workload.

\section{ETHICAL ASPECTS}

This study was approved by the Research Ethics Committee of the institution under Opinion n. 980.660/15, according to Resolution 466/12 of the National Health Council, on research involving human beings. Upon accessing the sent link, the respondent found the clear and Informed Consent Form and could only respond to the questionnaire if he/she accepted to participate in the study.

\section{RESULTS}

From the 67 health facilities included in the study, 38 (56.7\%) were public, 18 (26.9\%) were private and $11(16.4 \%)$ were teaching. The majority were large $(42 ; 62.7 \%)$ and $52(77.6 \%)$ were concentrated in the Southeast region. Among the 151 nurses, the female gender predominated (136; $90.1 \%)$, with a mean age of 35 years $(\mathrm{SD}=9.7$, variation 21-64), mean time of professional performance of 10.6 years $(\mathrm{SD}=9.2$, ranging from 3 months to 38 years), with 112 (74.2\%) working in the care function, and specialization $(76 ; 50.3 \%)$ as the most frequent post-graduation. Excluding nursing professors and managers, professionals $(\mathrm{n}=$ 135) were predominantly in intensive care units $(58 ; 42.9 \%)$ and in inpatient and specialized units $(58 ; 42.9 \%)$.

In relation to the scores obtained in each of the 28 interventions (Table 1 ), we found a variation in the mean values of 2.3 (Control of sample for exams, Research data collection, Shift change and Management of financial resources) to 3.2 (Preceptor: employee).
Table 1 - Descriptive statistics of the investigated intervention scores - São José do Rio Preto, SP, Brazil, 2016.

\begin{tabular}{|c|c|c|}
\hline Intervention & $M(S D)$ & $M D(Q 1-Q 3)$ \\
\hline Preceptor: employee & $3.2(0.9)$ & $3(4-3)$ \\
\hline Employee development & $3.1(0.9)$ & $3(4-3)$ \\
\hline Conflict mediation & $3.0(0.9)$ & $3(4-2)$ \\
\hline Physician Support & $3.0(0.9)$ & $2(4-2)$ \\
\hline Infection control & $2.9(0.9)$ & $3(4-2)$ \\
\hline Supervision & $2.9(0.9)$ & $3(1-2)$ \\
\hline Preceptor: student & $2.9(0.9)$ & $3(4-2)$ \\
\hline Employee supervision & $2.9(0.9)$ & $2(4-2)$ \\
\hline Technology control & $2.9(0.9)$ & $3(4-2)$ \\
\hline Documentation & $2.9(0.9)$ & $3(4-2)$ \\
\hline Health care information exchange & $2.9(0.9)$ & $3(4-2)$ \\
\hline Interpretation of laboratory data & $2.8(0.9)$ & $2(3-2)$ \\
\hline Control of supplies & $2.8(0.9)$ & $3(3-2)$ \\
\hline Transcription of prescriptions & $2.7(0.9)$ & $3(3-2)$ \\
\hline Quality control & $2.7(0.8)$ & $3(3-2)$ \\
\hline Environment control & $2.7(0.9)$ & $3(3-2)$ \\
\hline Delegation & 2.6(0.9) & $3(3-2)$ \\
\hline Emergency cart check & 2.6(0.9) & $2(3-2)$ \\
\hline Incident reports & $2.5(0.9)$ & $2(3-2)$ \\
\hline Multidisciplinary care evaluation & $2.5(0.9)$ & $2(3-2)$ \\
\hline Referral & $2.5(0.9)$ & $3(3-2)$ \\
\hline Verification of controlled substance & $2.5(0.8)$ & $2(3-2)$ \\
\hline Medication control & $2.5(0.9)$ & $3(3-2)$ \\
\hline Product evaluation & $2.4(0.8)$ & $2(3-2)$ \\
\hline Shift change & $2.3(1.0)$ & $2(3-1)$ \\
\hline Management of financial resources & $2.3(0.9)$ & $2(3-1)$ \\
\hline Control of sample for exams & $2.3(0.9)$ & $2(3-2)$ \\
\hline Research data collection & $2.3(0.9)$ & $2(3-2)$ \\
\hline
\end{tabular}

The score varies 1-4. The higher the score, the higher the workload.

Statistically significant associations $(\mathrm{p} \leq 0.05)$ between the 28 interventions investigated and the professional variables (position/function of participants) and institutional variables (legal nature and size) will be presented below.

Regarding the legal nature of health facilities (Table 2), a greater workload was reported in private hospitals for indirect care interventions. Physician support and Preceptor employee (Md 4) and differences in relation to teaching hospitals in Medication control, Environment control, Verification of controlled substance and Interpretation of laboratory data (Md 2).

Table 2 - Association between the workload generated by indirect care interventions and the legal nature of hospitals São José do Rio Preto, SP, Brazil, 2016.

\begin{tabular}{lccc}
\hline Intervention & $\begin{array}{c}\text { Teaching } \\
\text { Md(Q1-Q3) }\end{array}$ & $\begin{array}{c}\text { Private } \\
\text { Md(Q1-Q3) }\end{array}$ & $\begin{array}{c}\text { Public } \\
\text { Md(Q1-Q3) }\end{array}$ \\
\hline Legal Nature & & & \\
Medication Control & $2(2-3)$ & $3(2-3)$ & $3(2-3)$ \\
$\begin{array}{l}\text { Environment Control } \\
\text { Verification of controlled }\end{array}$ & $2(2-3)$ & $3(2-3)$ & $3(2-4)$ \\
$\begin{array}{l}\text { substances } \\
\text { Interpretation of laboratory }\end{array}$ & $2(2-3)$ & $3(2-3)$ & $3(2-3)$ \\
data & $2(-)$ & $3(2-3)$ & $3(2-3)$ \\
$\begin{array}{l}\text { Physician Support } \\
\text { Preceptor: employee }\end{array}$ & $3(2-3)$ & $4(3-4)$ & $3(2-4)$ \\
& $3(2-4)$ & $4(3-4)$ & $3(3-4)$ \\
\hline
\end{tabular}


In the association with the size of health institutions, median values varying from 2 to 3 in the Intervention Referral $(8,100)$ and from 2.5 to 4.0 in the Intervention Transcript of Prescriptions $(8,060)$ (Figure 1).

The associations of the subgroups below are shown to increase/increase little $(1,2)$ versus moderately increase/ greatly increase $(3,4)$. It is noted that the workload increases

Independent-Samples Kruskal-Wallis Test

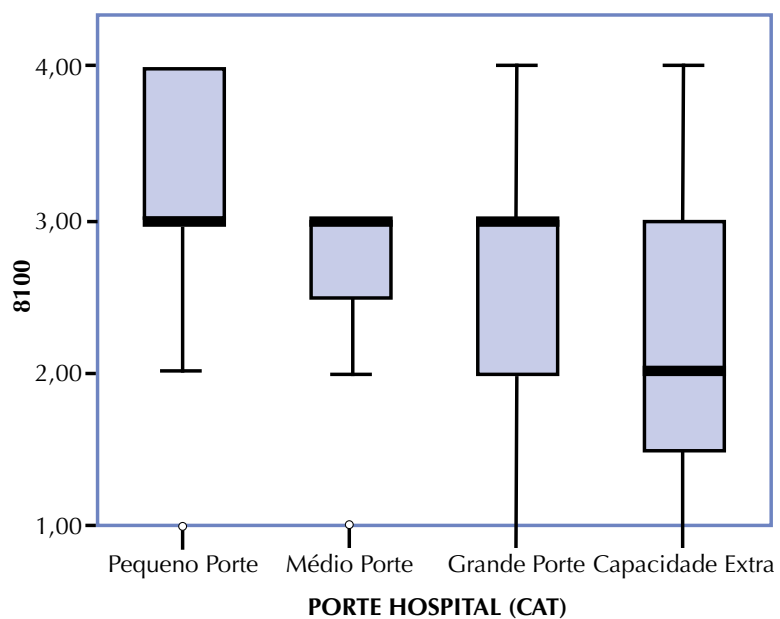

moderately or very much in private hospitals in relation to the legal nature of hospitals for the interventions Physician support, Employee supervision, Health care information exchange and Multidisciplinary care evaluation meeting. These findings and the degree of increase in workload associated with hospital size and units and services are presented in Table 3.

Figure 1 - Association between workload generated by the interventions Transcript of prescriptions $(8,060)$ and Referral $(8,100)$ and hospital size - São José do Rio Preto, SP, Brazil, 2016.

Table 3 - Interference of the degree of change of workload on the legal nature, size and unit/service of health facilities São José do Rio Preto, SP, Brazil, 2016.

\begin{tabular}{lcc}
\hline \multirow{2}{*}{ Intervention } & \multicolumn{2}{c}{ Increase in workload } \\
\cline { 2 - 3 } Legal nature & None/little & Moderate/high \\
Environment control & Teaching & Public* \\
Physician support & Teaching & Private* \\
Verification of controlled substance & Teaching & Public* \\
Interpretation of laboratory data & Teaching & Public** \\
Employee supervision & Teaching & Private* \\
Health care information exchange & Teaching & Private** \\
$\begin{array}{l}\text { Multidisciplinary care evaluation } \\
\text { meeting }\end{array}$ & Teaching & Private** \\
\hline Size & & \\
Infection control & Small/Extra & Large* \\
$\begin{array}{l}\text { Multidisciplinary care evaluation } \\
\text { meeting }\end{array}$ & Extra & Medium* \\
Referral & Extra & Small* \\
\hline Unit/service & & \\
Referral & UESP & Emergency* \\
\hline
\end{tabular}

*p $\leq 0.05 * * \mathrm{p} \leq 0.01$.

\section{DISCUSSION}

In the perception of nurses, indirect care interventions of Preceptor employee ( $\mathrm{M}=3.2)$, Employee development $(\mathrm{M}=3.1)$, Conflict mediation $(\mathrm{M}=3.0)$ and Physician support $(\mathrm{M}=3.0)$ most influence the nursing workload in the different practice scenarios.

Employee precepts refer to the guidelines and support planned to be provided to employees transferred from other units or services or newly admitted ${ }^{(2)}$. The qualification and the accompaniment of the new employee demand adequate time and space, so that there is no overlapping of educational and caring functions, thus increasing the workload ${ }^{(18)}$. This aspect was perceptible to the nurses in the study, and when the number of staff is reduced, the increase in workload may be even greater.

It is interesting to note that employee precepts do not appear in the list of the most frequent or medium-time interventions in Brazilian observational studies ${ }^{(13-16)}$. One explanation would be the inexistence or very small number of newly admitted employees and/or transferred from other units or services during the data collection period.

The intrainstitutional educational process is an important management tool associated with implementing safe care and retaining nurses in clinical practice ${ }^{(19)}$. Education also makes it possible to contextualize daily health work in facing scientific/technological innovations and concrete conditions for its effectiveness, significantly improving the professional competence of nursing ${ }^{(20)}$. Time planning for such activities has a direct influence on the adherence of professionals and teaching-learning ${ }^{(21)}$, and according to the study participants, there is an impact on nurses' workload.

In the hospital setting, nurses experience problems in interpersonal relationships with the medical staff, and also internal conflicts among nursing professionals ${ }^{(22-23)}$. Among the factors which generate disagreements are: a lack of collaboration between the team members ${ }^{(22)}$, the problems left by the previous shift, the high turnover of professionals and the work overload ${ }^{(23)}$.

These issues interfere with motivation, professional performance and are predictors of occupational stress, being 
reflected in the care provided ${ }^{(23)}$. In the perception of the participants of this study, these are factors which require significant time in nurses' routines. Leadership development strategies for a more participatory, interactive and dialogical management can support resolution of these situations ${ }^{(24)}$, optimizing the time and qualifying the work.

Support to the physician was identified among the four interventions which most require the nursing team's time, since it refers to the medical visit follow-up to the patient/family, orientation of this team on routines of the unit, request of new materials/equipment, availability of printed matter/medical records, among other functions ${ }^{(2,15)}$. This collaboration has been identified in national investigations $^{(15-16)}$ and confirmed in an international study ${ }^{(5)}$ as an activity which generates nursing overload.

The interventions considered more representative differ from other studies and showed greater time-consuming values

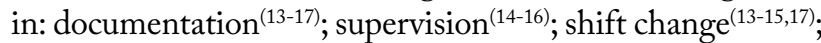
health care information exchange $\mathrm{e}^{(13,16-17)}$; and delegation ${ }^{(13-15)}$.

It was identified that Employee Precepts and Physician Support are activities which greatly increase the nurses'workload in private hospitals. It can be questioned if the nursing staff turnover is more representative in these institutions, however, no studies were identified which confirm this argument.

Aiming at the service qualification and maintaining competitiveness, some hospitals invest in accreditation programs which require new dynamics in the nurses' work, with effective communication, participation in clinical discussions and strategic management of the unit ${ }^{(25)}$. However, private hospitals have a lower number of professionals per bed and interventions such as Physician Support, Employee Supervision, Multidisciplinary Meetings and Patient Information Exchange can generate work overload. The latter has been identified among the indirect care activities which demand the nurses most time $-5.4 \%^{(13)}$ to $12.2 \% \%^{(16)}$.

In the participants' perception of this study, actions related to drug safety and control require a higher workload by the nurse, except in teaching hospitals. However, these hospitals still face challenges in relation to the barriers to prescription errors, dispensing, administration and safe maintenance of controlled substances ${ }^{(11)}$. Moreover, the infection control intervention only significantly increases the workload for nurses working in large hospitals (62.7\%). International evidence ${ }^{(26)}$ points to a reduction in the number of nursing personnel (a situation experienced by most
Brazilian health institutions) as a factor which can increase the number of infections related to health care.

Difficulties were encountered in contacting nurses due to the inexistence of a national database of this category being accessible to the researchers. The use of professional social networks and the snowball sampling method showed some efficiency, but it took time.

Several strategies (simple and attractive visuals, reminders to participants) were used to maximize the number of responses and thus reduce the risk of research bias, thus ensuring greater credibility of results ${ }^{(27)}$. Nevertheless, the response rate obtained was $14.8 \%$, using $100 \%$ of the returned questionnaires.

Studies conducted via web/e-mail have lower response rates than postal forms ${ }^{(27-28)}$, generally around $12.9 \%{ }^{(28)}$. Swedish researchers ${ }^{(29)}$ compared questionnaire response rates sent in two different ways - online and printed by post. The findings revealed response rates of $15 \%$ in the online form and $55 \%$ in the postal form.

It is known that the nursing workload is not restricted to direct care interventions to the patient, given the complexity of care management. This study brings evidence that supports this concept, and identifies activities indirectly related to the care process from the perception of nurses from different hospital practice scenarios, which have not been observed in previous research.

However, it is important to note that comparisons were made with direct observation studies using timekeeping. These different methods (timing vs. perception) can lead to different values in the results. In this way, future research is suggested for a more in-depth analysis of these interventions in measuring the time spent by the team, since some of them were not observed in previous studies.

\section{CONCLUSION}

This research has enabled us to rethink and rediscuss one of the components of workload: indirect care interventions to patients and the way these interventions impact the work dynamics from the perspective of nurses. Among the interventions investigated were: Conflict Mediation, Physician Support, Employee Development and Employee Preceptor.

These findings instrumentalize team management planning and refinement of workload measurement scales which may better reflect the nursing team's work in the practice scenario.

\section{RESUMO}

Objetivo: Avaliar a percepção de enfermeiros acerca do grau de interferência de intervenções de cuidados indiretos sobre a carga de trabalho da equipe e verificar a associação entre essas intervenções e as variáveis profissionais e institucionais. Método: Pesquisa survey por meio de correio eletrônico, conduzida junto a enfermeiros clínicos, gerentes de unidades e de serviço de oito estados brasileiros. Foi aplicado um questionário contendo 28 intervenções de cuidados indiretos e suas definições, propostas pela Classificação das Intervenções de Enfermagem. Resultados: Participaram 151 enfermeiros clínicos. Obteve-se taxa de resposta de 14,8\%. As intervenções de cuidados indiretos relatadas como as que mais aumentam a carga de trabalho foram: Preceptor: funcionário $(\mathrm{M}=3,2)$, Desenvolvimento de funcionários $(M=3,1)$, Apoio ao Médico $(M=3,0)$ e Mediação de conflitos $(M=3,0)$. Associações estatisticamente significantes entre as intervenções investigadas e as variáveis institucionais (natureza jurídica e porte) foram evidenciadas. Conclusão: Enfermeiros em distintos cenários de prática percebem que as intervenções de cuidados indiretos influenciam a carga de trabalho de forma diferenciada, com destaque para as demandas relativas ao acompanhamento e qualificação de funcionários.

Carga de Trabalho; Fluxo de Trabalho; Gerenciamento do Tempo; Recursos Humanos de Enfermagem no Hospital. 
RESUMEN

Objetivo: Evaluar la percepción de enfermeros acerca del grado de interferencia de intervenciones de cuidados indirectos sobre la carga laboral del equipo y verificar la asociación entre dichas intervenciones y las variables profesionales e institucionales. Método: Investigación survey por vía correo electrónico, conducida con enfermeros clínicos, gerentes de unidades y de servicio de ocho estados brasileños. Se aplicó un cuestionario conteniendo 28 intervenciones de cuidados indirectos y sus definiciones, propuestas por la Clasificación de las Intervenciones de Enfermería. Resultados: Participaron 151 enfermeros clínicos. Se obtuvo índice de respuesta del 14,8\%. Las intervenciones de cuidados indirectos relatadas como las que más aumentan la carga de trabajo fueron: Preceptor: funcionario ( $\mathrm{M}=3,2)$, Desarrollo de funcionarios ( $M=3,1)$, Apoyo al Médico $(M=3,0)$ y Mediación de conflictos $(M=3,0)$. Asociaciones estadísticamente significativas entre las intervenciones investigadas y las variables institucionales (naturaleza jurídica y porte) fueron evidenciadas. Conclusión: Enfermeros en distintos escenarios de práctica se dan cuenta de que las intervenciones de cuidados indirectos influencian la carga laboral de modo distintivo, con énfasis para las demandas relativas al acompañamiento y calificación de funcionarios.

\section{DESCRIPTORES}

Carga de Trabajo; Flujo de Trabajo; Administración del Tiempo; Personal de Enfermería en Hospital.

\section{REFERENCES}

1. Presotto GV, Ferreira MBG, Contim D, Simões ALS. Dimensões do trabalho do enfermeiro no contexto hospitalar. Rev RENE [Internet]. 2014 [citado 2017 jul. 12];15(5):760-70. Disponível em: http://www.periodicos.ufc.br/rene/article/view/3237/2492

2. Bulechek GM, Butcher HK, Dochterman J. Wagner CM. NIC: Nursing Interventions Classifications. Rio de Janeiro: Elsevier; 2016.

3. Perroca MG. The new version of a patient classification instrument: assessment of psychometric properties. J Adv Nurs. 2013;69(8):1862-8. DOI:10.1111/jan.12038/full.

4. Alghamdi MG. Nursing workload: a concept analysis. J Nurs Manag. 2016;24(4):449-57. DOI: 10.1111/jonm.12354.

5. Fagerström L, Vainikainen P. Nurses' experiences of nonpatient factors that affect nursing workload: a study of the PAONCIL instrument's nonpatient factors. Nurs Res Pract [Internet]. 2014 [cited 2018 May 10]; 2014:167674. Available from: https://www.ncbi.nlm.nih.gov/ pmc/articles/PMC4090478/

6. Myny D, Hecke A, Bacquer D, Verhaegue S, Gobert M, Deflorr T, et al. Determining a set of measurable and relevant factors affecting nursing workload in the acute care hospital setting: a cross-sectional study. Int J Nurs Stud. 2012;49(4):427-36. DOI: https://doi.org/10.1016/j. ijnurstu.2011.10.005

7. Swiger PA, Vance DE, Patrician PA. Nursing workload in the acute-care setting: A concept analysis of nursing workload. Nurs Outlook. 2016;64(3):244-54. DOI: https://doi.org/10.1016/j.outlook.2016.01.003

8. Santos NC, Fugulin FMT. Creation and validation of an instrument to identify nursing activities in pediatric wards: information for determining workload. Rev Esc Enferm USP [Internet]. 2013 [cited 2016 Feb 10];47(5):1052-60. Available from: http://www.scielo.br/ scielo.php?script=sci_arttext\&pid=S0080-62342013000501052

9. Perroca MG. Instrument for patient classification: users' opinions and analysis of healthcare indicators. Rev Esc Enferm USP [Internet]. 2008 [cited 2016 Feb 10];42(4):655-63. Available from: http://www.scielo.br/scielo.php?pid=S0080-62342008000400007\&script=sci_ arttext\&tlng=en

10. Ball JE, Murrells T, Rafferty AM, Morrow E, Griffiths P. Care left undone' during nursing shifts: associations with workload and perceived quality of care. BMJ Qual Saf [Internet]. 2014 [cited 2016 Feb 10];23(2):116-25. Available from: https://www.ncbi.nlm.nih.gov/pmc/ articles/PMC3913111/

11. Magalhães AMM, Moura GMSS, Pasin SS, Funcke LB, Pardal BM, Kreling A. The medication process, workload and patient safety in inpatient units. Rev Esc Enferm USP [Internet]. 2015 [cited 2016 Feb 18];49(n.spe):43-50. Available from: http://www.scielo.br/scielo. php?pid=S0080-62342015000700043\&script=sci_arttext\&tlng=en

12. Faeda MS, Perroca MG. Care management: agreement between nursing prescriptions and patients' care needs. Rev Latino Am Enfermagem [Internet]. 2016 [cited 2016 Nov 15];24: e2723. Available from: http://www.scielo.br/pdf/rlae/v24/0104-1169-rlae-24-02723.pdf

13. Garcia EA, Fugulin FMT. Nurses' work time distribution at the emergency service. Rev Esc Enferm USP [Internet]. 2010 [cited 2016 Nov 15];44(4):1032-8. Available from: http://www.scielo.br/scielo.php?pid=s0080-62342010000400025\&script=sci_arttext\&tlng=en

14. Bordin LC, Fugulin FMT. Nurses' time distribution: identification and analysis in a medical-surgical unit. Rev Esc Enferm USP [Internet]. 2009 [cited 2016 May 30];43(4):831-7. Available from: http://www.scielo.br/scielo.php?pid=S0080-62342009000400014\&script=sci_arttext\&tlng=en

15. Soares AVN, Gaidzinski RR, Cirico MOV. Nursing intervention identification in rooming-in. Rev Esc Enferm USP [Internet]. 2010 [cited 2016 May 30];44(2):307-16. Available from: http://www.scielo.br/scielo.php?pid=s0080-62342010000200010\&script=sci_arttext\&tlng=en

16. Souza CA, Jericó MC, Perroca MG. Measurement of nurses' workload in an oncology outpatient clinic. Rev Esc Enferm USP [Internet]. 2014 [cited 2016 May 30];48(1):97-103. Available from: http://www.scielo.br/scielo.php?script=sci_arttext\&pid=S0080-62342014000100097

17. Campos MS, Oliveira BA, Perroca MG. Workload of nurses: observational study of indirect care activities/interventions. Rev Bras Enferm [Internet]. 2018 [cited 2018 Feb 25]; 71(2):297-305. Available from: http://www.scielo.br/pdf/reben/v71n2/0034-7167reben-71-02-0297.pdf

18. Ward AE, McComb SA.Formalising the precepting process: a concept analysis of preceptorship. J Clin Nurs. 2018;27(5-6):e873-81. DOI: 10.1111 /jocn. 14203

19. Alilu L, Valizadeh L, Zamanzadeh V, Habibzadeh H, Gillespie M. A qualitative exploration of facilitators and inhibitors influencing nurses' intention to leave clinical nursing. Rev Esc Enferm USP [Internet]. 2016 [cited 2017 Mar 21];50(6):980-987. Available from: http://www. scielo.br/scielo.php?script=sci_arttext\&pid=S0080-62342016000600982\&lng=en\&nrm=iso\&tlng=en

20. Ting KeYT, Kuo CC, Hung $\mathrm{CH}$. The effects of nursing preceptorship on new nurses'competence, professional socialization, job satisfaction and retention: a systematic review. J Adv Nurs. 2017;73(10):2296-305. DOI: https://doi.org/10.1111/jan.13317 
21. Puggina CC, Amestoy SC, Fernandes HN, Carvalho LA, Báo ACP, Alves FO. Educação permanente em saúde: instrumento de transformação do trabalho de enfermeiros. Espaço Saúde. 2015;16(4):87-97.

22. Higazee MZA. Types and levels of conflicts experienced by nurses in the hospital settings. Health Sci J. 2015;9(6):1-6.

23. Amestoy SC, Backes VMS, Thofehrn MB, Martini JG, Meirelles BHS, Trindade LL. Conflict management: challenges experienced by nurseleaders in the hospital environment. Rev Gaúcha Enferm [Internet]. 2014 [cited 2016 Mar 21];35(2):79-85. Available from: http://www. scielo.br/scielo.php?script=sci_arttext\&pid=S1983-14472014000200079

24. Elfering A, Gerhardt C, Grebner S, Müller U. Exploring supervisor-related job resources as mediators between supervisor conflict and job attitudes in hospital employees. Saf Health Work. 2017;8(1):19-28. DOI: http://dx.doi.org/10.1016/j.shaw.2016.06.003

25. Gabriel CS, Bogarin DF, Mikael S, Cummings G, Bernardes A, Gutierrez L, et al. Perspectiva dos enfermeiros brasileiros sobre o impacto da acreditação hospitalar. Enferm Glob [Internet]. 2018 [citado 2018 maio 16];17(49):381-419. Disponível em: http://scielo.isciii.es/ pdf/eg/v17n49/pt_1695-6141-eg-17-49-00381.pdf

26. McGahan M, Kucharski G, Coyer F. Nurse staffing levels and the incidence of mortality and morbidity in the adult intensive care unit: a literature review. Aust Crit Care. 2012;25(2):64-77. DOI: https://doi.org/10.1016/j.aucc.2012.03.003

27. McPeake J, Bateson M, O'Neill A. Electronic surveys: how to maximize success. Nurse Res. 2014;21(3):24-6. DOI: 10.7748/ nr2014.01.21.3.24.e1205

28. Scott A, Jeon S, Joyce CM, Humphreys JS , Kalb G, Witt J, Leahy S. A randomized trial and economic evaluation of the effect of response mode on response rate, response bias, and item non-response in a survey of doctors. BMC Med Res Method. 2011;11:126. DOI: https:// doi.org/10.1186/1471-2288-11-126

29. Dannetun E, Tegnell A, Giesecke J. Parents' attitudes towards hepatitis B vaccination for their children. A survey comparing paper and web questionnaires. BMC Public Health [Internet]. 2007 [cited 2016 Mar 05];7:86. Available from: https://www.ncbi.nlm.nih.gov/pmc/ articles/PMC1887530/ 